However, the transition to low-carbon energy generation in Europe faces several challenges, such as the further deployment of electricity transmission capacities and new requirements for grid architecture. The existing European energy transmission infrastructure was designed to satisfy the needs of the fossil-fuel energy generation when energy sources were located near to energy consumption areas. Today, the new grid architecture has to integrate volatile and intermittent energy coming from RES located in different geographic areas, such as solar in the south of Europe and offshore wind in the north of Europe.

The need for the further deployment of electricity transmission grids is reflected in the Grid Development Plan 2013 and the European Commission Green Paper toward a secure, sustainable, and competitive European energy network. The commission proposal on guidelines for trans-European energy infrastructure calls for an urgent need for new power lines for three reasons: 1) foster market integration, 2) maintain a high level of system security, and 3) transport and balance electricity generated from renewable sources. Around 42,000 km of transmissions lines need to be upgraded or constructed in the European Union to secure market integration, security of supply, and accommodate the renewable expansion planned for 2020 , and the 2030 goals would require event a higher number.

\section{Social Challenges}

Currently, public opposition to the planned electricity infrastructure projects is a major barrier for further deployment. When the existing EU electricity transmission infrastructure was settled, public attitudes toward infrastructure projects were different than today. Fifty years ago, the infrastructure was regarded as a driver of socioeconomic growth, which was needed to increase the well-being of society. The traditional energy system had the goal of providing energy at the least possible cost and aspects such as impact on the environment and the interests of separate communities and people living in the vicinity of the energy generation projects were only of secondary importance. Current public attitudes, influenced by technological accidents and changed risks perceptions, are different, and there is opposition to infrastructure projects. Today the public is not only concerned by electricity generation at the least possible cost and the reliability of the energy supply but also by the impact on the environment and compatibility with goals of sustainable development. The view of the energy architecture is also changing with the availability of decentralized energy generation and the growing importance of renewable energy generation.

Based on available literature about public and social opposition to infrastructure projects, we classified all concerns into five groups: need, transparency, engagement, environment, and benefit.

$\checkmark$ Need implies a clear understanding and acceptance of the need of the project by stakeholders. It also includes linking the need for new infrastructure to problems, which this infrastructure can address. The need of the project is also discussed in light of the measures on energy efficiency or other options such as decentralized energy generation as well as discussion on the corridor alternatives.

$\checkmark$ Transparency is required in all aspects of the project as well as planning procedures, including information about which technology will be used and why and who will be carrying costs and benefits of the project: what stakeholders are involved and what will be the economic, environmental, and health impacts. It also includes concerns about how transparent the decisionmaking process is, if information is available, and it is clear and understandable on the risks and benefits of the project, regulatory procedures, stakeholders involved, and possibilities for engagement.

$\checkmark$ Engagement implies the involvement of stakeholders, whose knowledge might be beneficial for implementing the project with least possible impacts on human health and environment, into decision-making processes about infrastructure. It also implies concerns about the optimum time for engagement (not too late and not too early), how feedback from stakeholders was implemented in making decisions about the project, if there were alternatives to discuss, if feedback changed anything, and about voices being heard.

$\checkmark$ Environment foresees the implementation of actions to minimize impacts of infrastructure on human health such as electromagnetic frequencies (EMFs), on landscape such as visibility effects, or on the environment such as biodiversity.

$\checkmark$ Benefit includes the sharing of the benefits of infrastructure with those who had to make compromises and carried the costs of infrastructure, such as visibility impacts. It also goes beyond compensation for sacrifices to make the entire community a more attractive and better place to live.

\section{BestGrid Approach}

The BestGrid approach is an innovative approach to contribute to greater public acceptance of deployment of highvoltage (HV) electricity transmission grids. This approach is based on the principles of the European Grid Declaration (EGD), which requires the deployment of electricity grids with possible minimum impacts on nature. This approach was also formulated in the EGD on Electricity Network Development and Nature Conservation in Europe, which defines a set of principles on how to build power lines without harming nature. The declaration was developed under the guidance of the Renewables Grid Initiative (RGI) secretariat and signed by more than 30 large institutions across Europe. The approach foresees involvement of additional stakeholders, such as environmental nongovernmental organizations (NGOs), into decision-making processes about infrastructure deployment. It establishes frames for cooperation between NGOs and transmission service operators (TSOs) on the development of plans for public acceptance and environment 


\begin{tabular}{|c|c|c|c|}
\hline & Elia & TenneT & 50 Hertz \\
\hline Need & $\begin{array}{l}\text { Stakeholders mapping, interviews } \\
\text { to collect concerns }\end{array}$ & $\begin{array}{l}\text { Stakeholders mapping, } \\
\text { survey to collect concerns }\end{array}$ & $\begin{array}{l}\text { Stakeholders mapping, survey, or } \\
\text { interviews to collect stakeholders concern }\end{array}$ \\
\hline Transparency & $\begin{array}{l}\text { Workshop with inhabitants to } \\
\text { provide information about planning }\end{array}$ & $\begin{array}{l}\text { Public information events, } \\
\text { media campaign }\end{array}$ & $\begin{array}{l}\text { Two workshops in two communities to } \\
\text { provide information about planning }\end{array}$ \\
\hline Engagement & $\begin{array}{l}\text { NGOs providing comments on } \\
\text { action plans, roundtable discussion }\end{array}$ & $\begin{array}{l}\text { NGOs providing comments } \\
\text { on action plans. }\end{array}$ & $\begin{array}{l}\text { NGOs providing comments on action } \\
\text { plans, roundtable discussions }\end{array}$ \\
\hline Environment & $\begin{array}{l}\text { Roundtable discussion between } \\
\text { TSO and NGOs to discuss } \\
\text { environmental issues }\end{array}$ & $\begin{array}{l}\text { Inputs of local and } \\
\text { international NGOs during } \\
\text { public information events }\end{array}$ & $\begin{array}{l}\text { Roundtable discussion between TSO and } \\
\text { NGOs to discuss environmental issues, } \\
\text { media-campaign about EMFs, mobile } \\
\text { information office with measurements of } \\
\text { EMFs }\end{array}$ \\
\hline
\end{tabular}

protection as well as on joint implementation of these plans. In 2013, RGI was granted funds within the European Commission's Intelligent Energy Europe program to implement the verbal commitments contained in the EGD in real projects on the ground. This resulted in the project BestGridtesting better practices. The consortium brings together five TSOs (Elia, TenneT, 50Hertz, National Grid, and Terna); national NGOs Germanwatch and BirdLife International; a scientific research institute IIASA; and RGI as coordinator plus several subcontracted local NGOs, such as Bond Beter Leefmilieu Vlaanderen vzw (BBL), Natagora, Fédération Inter-Environnement Wallonie (IEW), DUH, and NABU.

During the three-year project, the BestGrid approach was implemented in five pilot projects. Here we focus on the process of implementation in four of them (Table 1). The approach has several steps starting from involvement in the project and giving them a chance to provide comments on the TSO's action plans on environment and on public acceptance.

The BestGrid targeted the issues of participation in several phases of the project planning processes. At all levels, public participation is possible however it happens more frequently at the level of the corridor and route planning (Figure 1).

During public information events, stakeholders could express their concerns, receive answers from TSO representatives, and request additional information. The roundtable discussions helped to express concerns about impacts on environment and possibilities for engagement. Environmental NGOs also provided their advice on the implementation of environmental protection in planning of TSO projects. The BestGrid process also included several project meetings where the BestGrid team members discussed the progress of action plans and provided their comments and advice.

\begin{tabular}{|c|c|c|c|c|}
\hline \multicolumn{2}{|l|}{$\begin{array}{l}\text { Needs Assessment } \\
\text { Level } 1\end{array}$} & \multicolumn{2}{|c|}{$\begin{array}{l}\text { Corridor/Route Planning } \\
\text { Level } 2 \text { (a Two-Step Procedure in Some } \\
\text { Countries) }\end{array}$} & \multirow{2}{*}{$\begin{array}{l}\text { Construction and } \\
\text { Operation } \\
\text { Construction and } \\
\text { Operation }\end{array}$} \\
\hline Scenarios & $\begin{array}{l}\text { Grid Development } \\
\text { Plan }\end{array}$ & Corridors & Detailed Routes & \\
\hline $\begin{array}{l}\text { Scenario } \\
\text { Development } \\
\text { EU/National }\end{array}$ & $\begin{array}{l}\text { Grid or Network } \\
\text { Development Plans } \\
\text { EU (TYNDP)/ } \\
\text { National }\end{array}$ & Corridors & $\begin{array}{l}\text { Detailed } \\
\text { Determination } \\
\text { of Routes }\end{array}$ & \\
\hline $\begin{array}{l}\text { What are the likely } \\
\text { future develoments } \\
\text { of electricity } \\
\text { generation and } \\
\text { demand? }\end{array}$ & $\begin{array}{l}\text { What projects are } \\
\text { needed? }\end{array}$ & $\begin{array}{l}\text { In which corridor } \\
\text { should the power } \\
\text { line be built? }\end{array}$ & $\begin{array}{l}\text { Which route should be } \\
\text { determined in detail? } \\
\text { Where will pylons for } \\
\text { cables) be built? }\end{array}$ & \\
\hline & & Spatial Planning & $\begin{array}{l}\text { Corridor and Route } \\
\text { Planning }\end{array}$ & \\
\hline
\end{tabular}

figure 1. The phases of the project planning process. (Source: Germanwatch, based on BNetzA 2015.) 


\section{The data in different pilot projects \\ were collected jointly by BestGrid partners \\ for the period 2013-2015.}

\section{Pilot Projects}

Elia is the Belgian TSO, which has over $8,000 \mathrm{~km}$ of lines. Two pilot projects of Elia are included in the BestGrid approach. One is the $150-\mathrm{kV}$ onshore Braine-l'Alleud and Waterloo underground cable. In 2014, Elia canceled the pilot because of new forecasts regarding electricity consumption in the region, which showed that the need for the new cable connection disappeared.

The second pilot project is the Stevin power line (see Figure 2), which is one of the largest new HV power lines planned in Belgium, with a total length of $40 \mathrm{~km}$ and a $380-\mathrm{kV}$ $\mathrm{HV}$. A part of the project is underground cable because of the environmental concerns.

TenneT in cooperation with TransnetBW is currently realizing the largest energy transmission infrastructure project in Germany, the Sued.Link (see Figure 3). The HVdc power line of around $800 \mathrm{~km}$ with a transmission capacity of $4 \mathrm{GW}$ will allow electricity generated from wind energy in the North Sea to be delivered to consumers in the middle and the south of Germany. The project is planned to go through densely populated regions with on average 235 people living on each square kilometer.

50 Hertz (see Figure 4) is managing $220-\mathrm{kV}$ and $380-\mathrm{kV}$ electricity grids in the north and east of Germany with the overall length of $10,000 \mathrm{~km}$. This grid integrates around $40 \%$ of all wind energy generated in Germany and provides electricity to 18 million people. $50 \mathrm{Hertz}$ is planning to

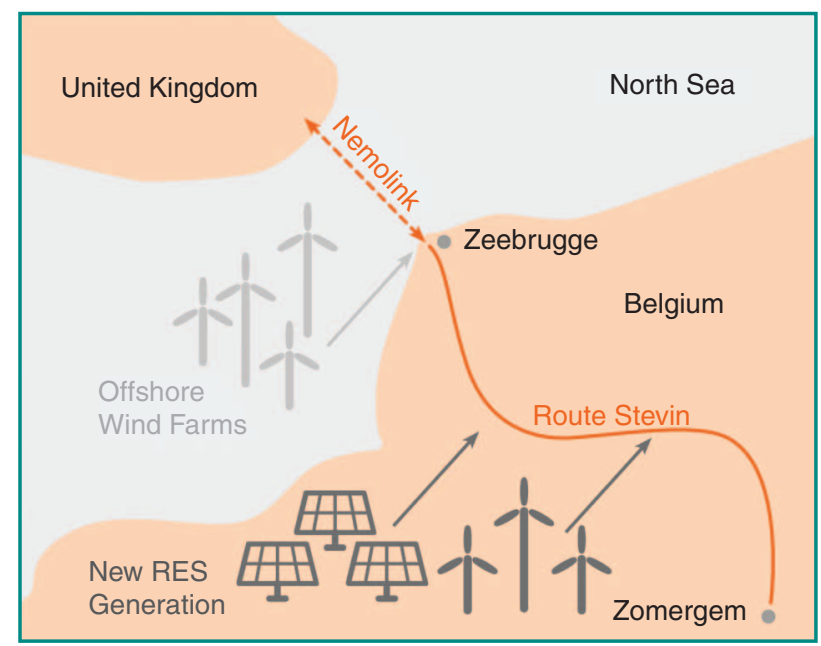

figure 2. The Stevin connection. (Source: Germanwatch, based on Elia 2014.) construct the 29-km Bertikow-Pasewalk 380-kV overhead line, which will replace the existing $220-\mathrm{kV}$ and $110-\mathrm{kV}$ lines to integrate growing volumes of electricity from renewable energy sources.

\section{Concerns of Stakeholders}

The data in different pilot projects were collected jointly by BestGrid partners (Figure 5) for the period 2013-2015. IIASA developed data collection protocol, provided inputs and methodological guidance on different data collection methods, and analyzed the results. IIASA, Germanwatch, and RGI provided records of public information events and roundtable discussions for all pilot projects. National NGOs, such as IEW, BBL, and NABU, recorded concerns for separate pilot projects. NABU and IEW provided feedback forms about the BestGrid project. IEW and BBL conducted extensive interviews with local stakeholders.

The data collection included different methods such as stakeholders mapping, in-depth interviews with key stakeholders, observations and recording on side of the workshop with local and regional authorities, as well as roundtable discussions between NGOs and environmental authorities. Further activities, such as observations of public information events and onsite surveys to collect feedback from stakeholders, were also conducted.

\section{Need}

Concerns about the need of the project were most frequently expressed across all five pilot projects. We have examples from Waterloo-Braine d'Alleud, Stevin, Sued.Link, and Bertikow-Pasewalk pilots (see Table 2). In all pilots, we recorded a low level of awareness among inhabitants about the need of the project for climate change mitigation.

In the case of the Elia Waterloo-Braine d'Alleud underground cable connection, the need was not clear, as there was no significant population growth in Waterloo, several electricity consuming industries were disappearing, and the number of commercial consumers in the region was not planned to increase. The need was also questioned in light of ongoing effects to implement energy efficiency measures. Public administration stakeholders were also concerned on the security of the electricity transmission network and how Elia can guarantee the reliable supply of electricity during construction works and after, as the cable is a relatively new technology. After the news that the project was canceled, stakeholders were mainly concerned about how such news 
Energiebilanzen Nach Bundesländern

HGÜ-Leitungen Überbrücken das wachsende Nord-Süd-Getälle

1. Sued Link

Nord Link

" . - - Weitere HGÜ-Leitungen

- - Anbindung Von Offshore-Windparks

$\uparrow$ Windparks Auf See

(I) Kernkraftwerk

Energiebilanz Nach Regionen Eine Prognose Für 2024

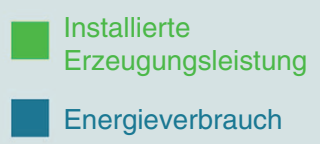

Quellen:

2. Entwruf Netzentwicklungsplan 2014
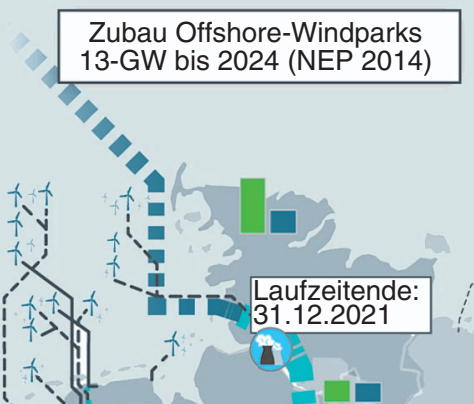

Zubau Onshore-Windparks 55-GW Instaliierte Leistung Bis 2024 (NEP 2014)

2.

Geplanter Stromtrassen-Neubau

Es Werden 3.800-km Neue

Stromtrassen Benötigt,

Davon 2.300-km HGÜ-Leitungen
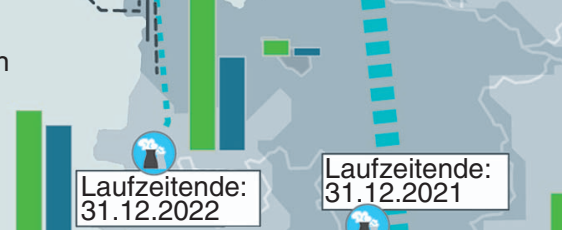

aufzeitende: 31.12.202
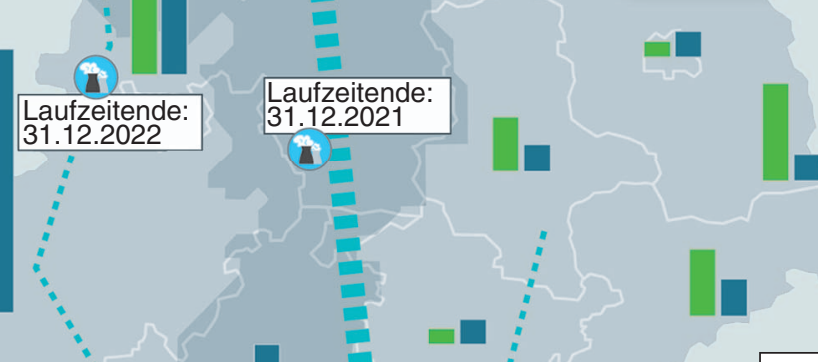

Laufzeitende:

31.12.2015

Ungleichgewicht Im Norden Wird Viel Mehr Energie Erzeugt, Als Verbraucht Wird. Im Süden Herrscht Dagegen Seit Der Abschaltung Der Ersten

Kernkraftwerke

Ein Energiedefizit

figure 3. The Sued.Link. (Used with permission from Sued.Link.)

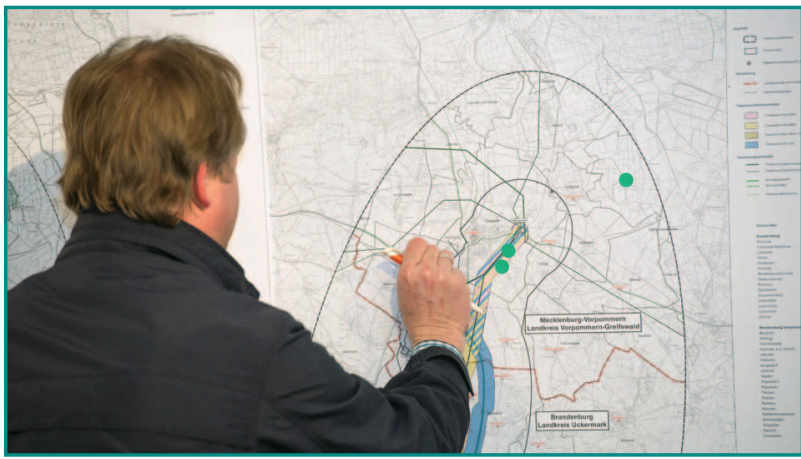

figure 4. The public information event 50Hertz. (Used with permission from BestGrid, 2015.)

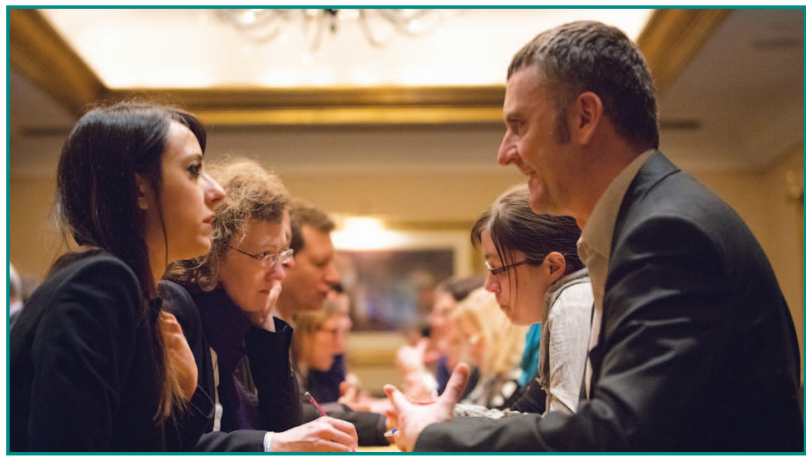

figure 5. The BestGrid Stakeholders event. (Used with permission from RGI.) 


\section{table 2. Data collection and actions of BESTGRID partners in five pilot projects.}

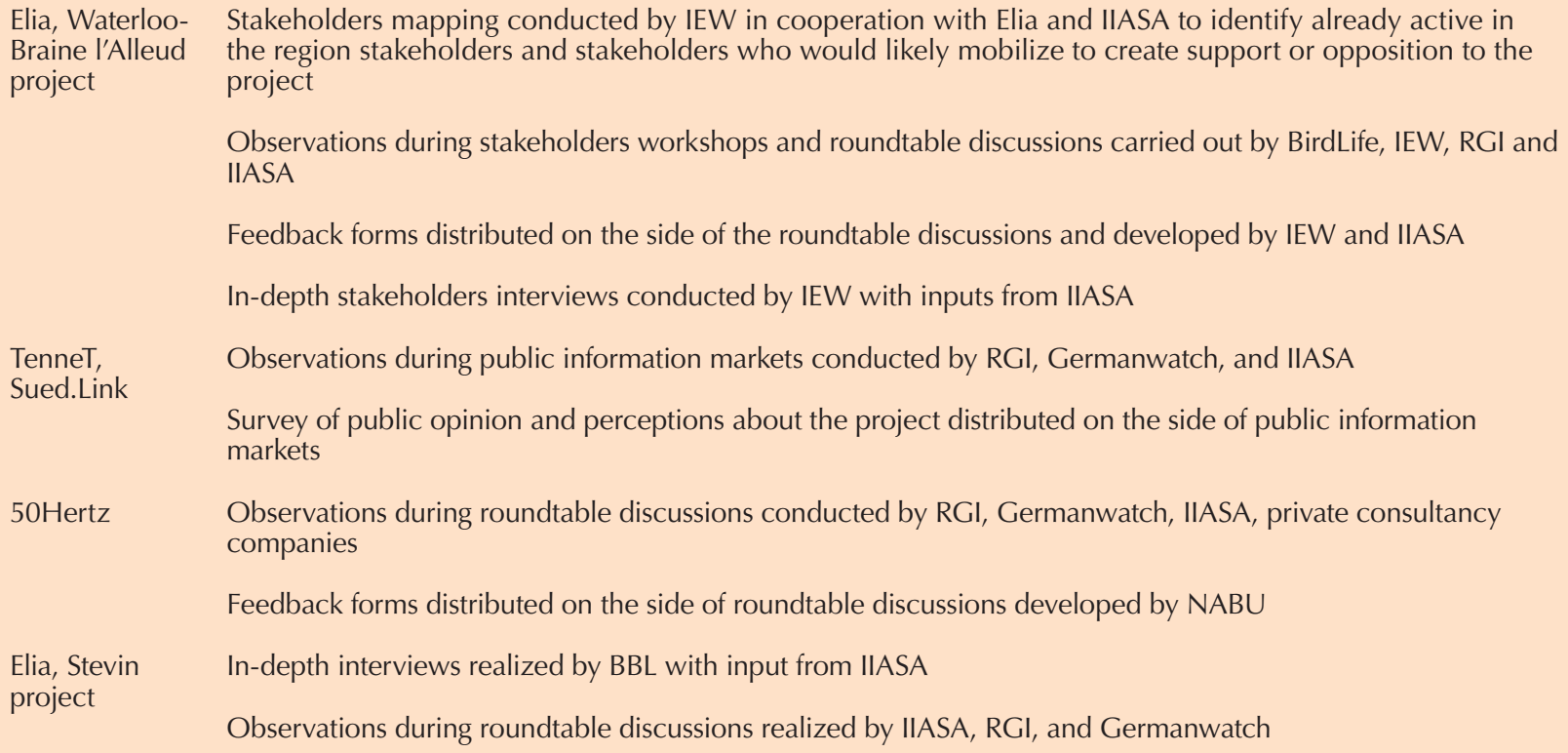

will affect the need for similar projects in the future and the willingness of stakeholders to participate.

In the case of the Stevin project, inhabitants questioned the need of interconnection with United Kingdom, as connections already existed with France, The Netherlands, Germany, and Scandinavia. People also questioned if energy demand was really growing and if there was really a shortage of supply, which would argue for the new line. Stakeholders also questioned why this new infrastructure couldn't be bundled with other infrastructure projects such as railways or the Leopold canal.

Stakeholder concerns about a priority corridor for Sued. Link and its alternatives included doubts about the need for the project, in general, and the arguments for a more decentralized energy system, especially in light of further deployment of renewable energies for decentralized generation in the south of Germany. These doubts were also supported by fears that new electricity lines will be constructed to transmit electricity generated from coal. Inhabitants also were concerned that electricity consumed in another federal state would be transmitted in the vicinity of their community.

In the pilot of 50Hertz Bertikow-Pasewalk connection, stakeholders questioned the need for the project in affected communities as well as the economic criteria to construct the overhead line instead of underground cable.

\section{Transparency}

Regarding the underground Waterloo-Braine D'Alleud cable, environmental stakeholders requested more transparent information of the planned corridor with detailed maps about potential electricity suppliers, which will be transmitted by the planned project, as well as estimations about future energy demand in the region, impact of construction works, their length, possible restrictions on mobility, and the process of realization of the project.

In the Stevin pilot, inhabitants requested visualization of the project such as maps, three-dimensional visualization, pictures, and drawings. Other requests for transparency were the availability of information on the environmental impact assessment of the project online, simplification of the technical language of the reports, availability of the federal development plan, and more details on planning and permitting procedures as well as publication online of comments from stakeholders and answers to their concerns.

For Sued.Link, concerns were expressed about the transparency of criteria for the selection of a priority corridor and the planning process. Stakeholders also requested additional information about overall planning for grid extension projects in Germany and in the European Union in a form of a map showing all planned transmission grids projects approved by BNetzA or foreseen by law as well as further power grid projects in the area, which will be affected by the SUED.LINK project. This could include maps showing projects according to the German law, maps of the German and European 380-kV power grids, as well as any further TenneT $380 \mathrm{KV}$ projects in the area of SUED.LINK.

The concerns about the selection of a priority corridor for the SUED.LINK also included terminology of "priority corridor," which led to misunderstandings. In Germany, it is required by law to present the "priority corridor" and its alternatives to explain their impacts. Such terminology makes it difficult to communicate that this priority corridor has not been fixed yet and is still subject to change. The better terminology would be a "proposed route" or a "draft route."

In the Bertikow-Pasewalk connection, requirements included more transparency about the decision-making 
process, planning procedures within 50Hertz, sources of transmitted electricity and how decisions were addressed in the regional need development plan, and which data were used for development of electricity demand assessment and renewable energy generation in the region. More information was also requested about the impacts from construction of new lines on leveled costs of electricity, types of planned pylons, and possible impacts from EMFs. Several concerns were expressed about the transparent calculation of compensations volumes.

\section{Engagement}

Stakeholders in the region of the underground WaterlooBraine D'Alleud cable had already participated in discussions about infrastructure projects, such as land planning, mobility projects, and the deployment of a $150-\mathrm{kV}$ line. However, this experience was mostly limited to providing feedback about the project. Regarding underground cable, stakeholders were concerned about two issues: 1) the right time for participation and 2) if their voices would be heard and if participation will change anything. The first issue was due to the fact that information events took place early enough, but they were not followed by reaction from the community side. Therefore, it might be too early to organize such events as people are not really aware of the project and do not know much about it. There were also concerns about the impact on volunteers, who had committed their time by participating in meetings and discussions and their willingness to participate in such meetings in the future, for the decision to cancel the project .

In the Stevin pilot, there were concerns that participant feedback would not be addressed. Participants were also asking why politicians were absent during information sessions. Participating public authorities were concerned that a number of local organizations were not present and that concerns of local communities about the project were not taken seriously by regional government.

In the Bertikow-Pasewalk connection, participants requested information about stakeholders who were involved in the development of renewable energy scenarios in the region. The recommendations were also to distribute information about possibilities for participation through official journals. Inhabitants mentioned the need for involvement of technical committees in local parliaments and local politicians as multipliers of information. Concerns were also expressed about time of participation, which should be also convenient for people who are at work during daytime.

\section{Environment}

In the Waterloo-Braine D'Alleud cable, the majority of stakeholders expressed concerns regarding construction work and, connected with them, restrictions of mobility and noise. There are concerns about possible impacts from construction works on buildings in proximity to the project, such as accessibility to the nursing house during construction works. Concerns were expressed about the regulatory framework on environment protection and how it will be applied in the case of this project, such as the relationship between the schemes of regional development, the need to preserve green areas, and the proximity to the urban centers. Environmental stakeholders also believed that there is a need for holistic analysis of impacts on environment from all types of existing infrastructure in the communities' infrastructure. Environmental stakeholders were concerned about health impact of the underground cable.

In the Stevin pilot, inhabitants were concerned with the visibility of electricity transmission infrastructure as well as negative impacts on biodiversity and noise. They requested independent studies on environmental impacts for identified corridors and on electromagnetic fields as well as an evaluation of cumulative effects from all infrastructure projects on human activities and environment.

In the SUED.LINK of TenneT, several concerns were raised about the visibility of the transmission infrastructure. Inhabitants proposed alternative forms to provide information about the planned infrastructure, such as the three-dimensional visualization that could help them to better understand the impact on the landscape. Such visualizations could also make different phases of the planning process more tangible and to show decision making in each phase and how it relates to official planning and permitting. Visualization could also provide information about actual models of pylons and how they are changing the landscape. The lack of visual material about pylon design and alternatives was frequently mentioned as a point for improvement. Interestingly, those communities with strong opposition to SUED.LINK, such as Elfershausen and Bad Brückenau, already had experience with renewable energy infrastructure, which was visible and affecting the landscape. But this infrastructure was mainly for decentralized small-scale energy generation, such as solar photovoltaics.

In the Bertikow-Pasewalk connection, stakeholders were discussing possibilities for coupling a new line with an existing $110-\mathrm{kV}$ line to decrease impacts on environment. At the same time, they were discussing alternatives to the corridor of $110 \mathrm{kV}$, which was constructed several years ago, when little attention was given to mitigating possible impacts on environment and human settlements and on agriculture and landscape. Stakeholders were requesting consideration of other existing infrastructure projects such as gas pipelines and construction of lines along these projects to minimize impacts on environment, taking into consideration that this infrastructure has already impacted the environment and human activities around it. Other concerns included impacts from electromagnetic fields on human health and from construction works on the recreation and nature-protected areas around the community.

\section{Benefit}

In the Waterloo-Braine l'Alleud project, stakeholders were concerned about compensation for local communities, 
affected by the project. They recommended that compensation should be for the deployment of infrastructure itself and for impacts on everyday life from construction work, such as limited mobility. At the same time, they were also interested about possible benefits from the project. Stakeholders saw an opportunity to provide benefits to local communities, such as, for example, modernizing transport routes during the construction period.

In the Stevin pilot, inhabitants were a requesting fair distribution of costs and benefits. They were concerned that the burden of the project would be on the shoulders of local communities and the benefits will go to energy companies. They were also requesting equal compensation for property owners underneath new lines and under already existing lines. Another request was that the project should provide an added value for affected communities. Inhabitants were suggesting the introduction of expropriation/compensation rules similar to the rules existing in The Netherlands. Public authorities were recommending providing alternative forms of compensation such as funding of local projects, taxes on pylons or fees based on the number of kilometers, as well as further development of legal framework for compensation.

In the Bertikow-Pasewalk connection, the expressed concerns included compensation to peasant unions for impacts of two lines, volumes of compensation, and compensation in cases of impacts from several infrastructure projects or a special discussion of cases when landowners already received compensation for other infrastructure projects. Other concerns included costs of the project and their possible distribution across the country instead of being a major burden for the region and possibilities for compensation measures regarding legally established protection areas.

\section{Discussion}

As Table 3 shows, even though pilot projects in BestGrid were different in their nature, involving large and smallscale projects and underground and overhead lines, concerns were expressed in all projects and regarding all five guiding principles.

Separate actions of TSOs were successful in addressing issues of public and social acceptance. These actions targeted the guiding principle "need" and included different forms of stakeholders' information events, such as roundtable discussions or information markets. The following actions were positively perceived by stakeholders: provision of detailed maps about alternatives of corridors, possibility for dialogue with TSO employees on important stakeholder questions, as well as involvement of local NGOs for the organization and moderation of information events. The entire BestGrid process was also successful in addressing the guiding principle "need." However, this has to be seen against the background of the political circumstances in the respective

\begin{tabular}{|c|c|c|c|c|}
\hline Guiding Principle & $\begin{array}{l}\text { Elia (Underground } \\
\text { Cable) }\end{array}$ & Elia (Stevin Project) & TenneT & 50 Hertz \\
\hline Needs & $\begin{array}{l}\text { Unclear need as it } \\
\text { is not clear if energy } \\
\text { consumption in the } \\
\text { region will be growing }\end{array}$ & $\begin{array}{l}\text { Need of the project location } \\
\text { and communication about } \\
\text { the need of the project }\end{array}$ & $\begin{array}{l}\text { Unclear need } \\
\text { because of } \\
\text { decentralized } \\
\text { generation options }\end{array}$ & $\begin{array}{l}\text { Need for } \\
\text { transmission of } \\
\text { electricity to Poland }\end{array}$ \\
\hline Engagement & $\begin{array}{l}\text { Optimum time for } \\
\text { engagement, believe } \\
\text { about impacts of } \\
\text { participation }\end{array}$ & $\begin{array}{l}\text { Early involvement of local } \\
\text { authorities, guided process of } \\
\text { engagement, feedback from } \\
\text { local stakeholders on routing }\end{array}$ & $\begin{array}{l}\text { Place of public } \\
\text { information events, } \\
\text { where everybody } \\
\text { could pass by and not } \\
\text { only already informed } \\
\text { stakeholders }\end{array}$ & $\begin{array}{l}\text { Information about } \\
\text { who will be involved } \\
\text { in discussions about } \\
\text { the project }\end{array}$ \\
\hline Transparency & $\begin{array}{l}\text { Planned corridor, sources } \\
\text { of electricity }\end{array}$ & $\begin{array}{l}\text { Details of the project and } \\
\text { how it will affect everyday } \\
\text { life, criteria for decision } \\
\text { making, clear information, } \\
\text { trusted communication } \\
\text { channels }\end{array}$ & $\begin{array}{l}\text { Criteria of selecting } \\
\text { priority corridor, } \\
\text { sources of electricity }\end{array}$ & $\begin{array}{l}\text { Planning procedures, } \\
\text { source of electricity, } \\
\text { EMFs }\end{array}$ \\
\hline Environment & Impacts on human health & $\begin{array}{l}\text { Noise from cooling systems } \\
\text { and cables, need for } \\
\text { independent SEA and EIA, } \\
\text { coherent approach for } \\
\text { several infrastructure projects }\end{array}$ & $\begin{array}{l}\text { Visibility impacts, } \\
\text { security of } \\
\text { transmission system, } \\
\text { impacts from EMFs }\end{array}$ & $\begin{array}{l}\text { Impacts on } \\
\text { environment, } \\
\text { visibility impacts, } \\
\text { impacts from EMFs }\end{array}$ \\
\hline Benefits & $\begin{array}{l}\text { Modernization of routes } \\
\text { during construction } \\
\text { period, possible benefits } \\
\text { from the project for local } \\
\text { communities }\end{array}$ & $\begin{array}{l}\text { Fair compensation between } \\
\text { inhabitants, clear rules of } \\
\text { compensation, regulatory } \\
\text { framework, compensation to } \\
\text { environment }\end{array}$ & $\begin{array}{l}\text { Distribution of } \\
\text { burden and benefits } \\
\text { between different } \\
\text { communities and } \\
\text { provinces }\end{array}$ & $\begin{array}{l}\text { Compensation } \\
\text { to land owners, } \\
\text { compensation to } \\
\text { environment }\end{array}$ \\
\hline
\end{tabular}


countries, discussion about monster pylons, technology, and serious struggles about energy policy.

The recommendations to the national governments were to provide more background information about the need for energy transition and new power lines. This information could be provided not only at the national level but would also be supported by governments at the local level. The discussion about alternative options included possibilities for bundling with existing lines, for different technologies, such as overhead lines versus underground and pylon types. The recommendation was to provide additional information in a clear and concise matter about different technological options as well as their advantages and disadvantages.

However, the guiding principles "transparency" and "environment" were only partially addressed, not for the lack of effort but because of changes in concerns with new information. Much work was done to address concerns about transparency and environment. The successful actions are described in the handbooks developed by Germanwatch and BirdLife International, but new concerns appeared with the increased level of awareness. This changing nature of concerns about transparency and environment shows that there is a need for constant dialogue with stakeholders. Even though there were several public information events to provide more transparency about the pilot projects and the decision-making processes, such as the information markets of TenneT, they addressed existing questions but then new questions appeared. For instance, when concerns about transparency of decision criteria about alternative routings were addressed, new questions appeared about the type of pylons or impacts of EMFs on human health. The results showed that providing more transparent information increased the level of awareness about the pilot projects and their details but raised more questions about additional details. The recommendations across all four pilot projects were to provide a website with clear, transparent, and easy-to-read information not only about the project but also about the decision-making processes and documents, like regional development plans. Addressing the guiding principle "environment," BestGrid provided recommendations on compensation measures to environment as well as on environment protection measures, such as protection of biodiversity and migratory birds.

The guiding principles "engagement" and local "benefit" were not addressed from the point of view of stakeholders. The involvement of local NGOs in public information campaigns was perceived very positively by stakeholders.

The recommendations were to involve organized stakeholders right from the beginning, in meetings to discuss the need for the project. Some stakeholders recommended that NGOs and civil society organizations should be involved early enough for their input to be taken into consideration. Other stakeholders mentioned that the participatory process was launched at too early of a stage; it would be better to start it at a later stage when there was greater certainty about the project. Another recommendation was to contact others for their opinions: local government or people independent from politics, those leading the stakeholders' engagement process, and all inhabitants in direct vicinity to power lines.

The results also show that concerns about benefits or compensation were raised less frequently. However, the measures to address these concerns taken in frames of BestGrid were also least successful. The public information events provided an opportunity for stakeholders to express their opinion and wishes about possible benefits and compensation from the project, such as the creation of a fund, fair distribution of compensation across communities, and transparent rules for compensations. It was out of the scope of BestGrid to implement these measures. If we look at the concerns about benefits and compensations, most of them were about compensations than benefits, and almost all of these concerns were about transparent rules for compensation and fairness, for instance, equal compensations between different communities or also compensations for inhabitants who were affected by other types of infrastructure.

\section{For Further Reading}

A. Battaglini, J. Lilliestam, A. Haas, and A. G. Patt, "Development of SuperSmart grids for a more efficient utilization of electricity from renewable resources," J. Cleaner Product., vol. 17, no. 10, pp. 911-918, 2009.

A. Battaglini, N. Komendantova, P. Brtnik, and A. Patt, "Perception of barriers for expansion of electricity grids in the European Union," Energy Policy, vol. 47, pp. 254-259, 2012.

European Commission. "A roadmap for moving to a competitive low carbon economy in 2050," Communication from the Commission to the European Parliament, the Council and the European Economic and Social Committee and the Committee of the regions. European Commission, Brussels, 112 final report, Mar. 8, 2011.

European Commission. (2013). Regulation (EU) No 347/ 2013 of the European Parliament and of the Council of 17 April 2013 on guidelines for trans-European energy infrastructure and repealing Decision No 1364/2006/EC and amending Regulations (EC) No 713/2009, (EC) No 714/2009 and (EC) No 715/2009. [Online]. Available: http:// eur-lex.europa.eu/legal-content/EN/TXT/PDF/?uri=CELE $\mathrm{X}: 32013 \mathrm{R} 0347 \&$ from $=\mathrm{EN}$

ENTSO-E. “Ten-year network development plan,” European Network of Transmission System Operators for Electricity (ENTSO-E), Brussels, 2012.

\section{Biographies}

Nadejda Komendantova is with the International Institute for Applied Systems Analysis, Vienna, Austria, and ETH Zurich, Switzerland.

Antonella Battaglini is with the Potsdam Institute for Climate Impact Research and the Renewable Grid Initiative, Berlin, Germany. 